\title{
태국의 대외원조 기본방향과 동향
}

태국 정부는 2004.10월 선진국으로부터의 원조를 총괄 관리하던 외교부 기술경제협력국(DTEC)을 태 국국제협력단(TICA)으로 개편하고, 라오스, 미얀마, 캄보디아 등 인접국에 집중적으로 기술원조를 공여 하는 한편, 선진 원조공여국 및 국제기구와의 개발협 력 파트너로서의 역할 수행에 많은 노력을 기울이고 있는 바, 신생 원조공여국으로 변모를 꾀하고 있는 태 국정부의 대외원조 기본방향과 동향은 아래와 같음.

\section{I . 대외원조의 기본방향}

무요원칙 : '남남협력' 및 '개발협력을 위한 파트 너십

ㅁ목표 : 인간복지를 위한 호혜 및 번영 달성

\section{II. 대외원조 동향}

\section{1. 원조 중점지역 및 분야}

ㅁ 인접 최빈국에 집중적으로 원조 공여

- 2003년도 태국의 전체 ODA 167 백만 달러의 $90 \%$ 이상을 라오스, 미얀마, 캄보디아, 몰디브 의 도로, 교량, 댐, 발전소 등 기본 인프라 구축 에 사용

\section{ODA 규모}

ㅁ중소득국가인 태국의 ODA 규모는 GNI 대비 $0.13 \%$ 로 미국(0.15\%)과 거의 같은 수준이며, 최빈 국에 대한 ODA 지원비율은 93\%로서 2003년도 $\mathrm{OECD} \mathrm{DAC}$ 평균비율(33\%)을 훨씬 상회함.

ODA 대부분이 유상원조로 자국의 재화와 용역이 연계된 조건부 원조(tied aid)임.

-ODA 유무상 비율 : $88 \%$ 대 $12 \%$

ㅁ $\mathrm{ODA}$ 의 $86 \%$ 가 개도국 인프라 사업에 투입되고 사 
회적 부문에는 $9 \%$ 정도만 지원됨.

\section{3. 공동협력사업 추진}

TICA는 현재 일본과 동등한 파트너십을 원칙으로 한 'Japan-Thailand Partnership Programme, Phase I' 프로그램을 추진 중임.

- 제3국을 위한 연수프로그램, 제3국에 태국 전문 가 파견, 3 자간 협력사업(triangular cooperation) 등이 해당됨.

- 일본정부는 자금을, 태국은 동남아지역 특성에 맞는 전문지식을 상호 제공함.

- 태국이 제공하는 전문지식은 종래의 교육, 공중 보건, 농업분야에서 교통, 경제, 금융, 과학기술 분야로 영역이 확대되고 있음.

\section{4. 새로운 양자간 프로그램 도입}

ㅁ 인접 최빈국 현지주민과의 상호이해 증진을 도모 하고자 청년봉사단원을 파견하는 'Friends From Thailand' 프로그램을 도입함.

\section{5. 대 아프리카지역 원조}

ㅁ 태국은 1978년부터 아프리카 국가를 대상으로 연 수생초청, 전문가파견을 위주로 한 원조를 계속 실시하고 있음.

\section{6. 대 국제기구 및 $\mathrm{OECD}$ 활동강화}

ㅁ 태국은 UN, IMF, World Bank, ADB 등 국제기 구에도 지속적으로 기여하고 있음.

- UN 기여금 : 2003 년에 7.8 백만불 지원
- UN 여성개발펀드 : 1976 년부터 기여금 제공, 2002년부터는 매년 1만불씩 지원

- $\mathrm{ADB}$ : 1997년부터 $\mathrm{ADF}$ 에 총 8백만불 지원

- Global Fund : 에이즈, 결핵, 말라리아 퇴치를 위해 5 년동안 1 백만불 지원 예정

$\mathrm{OECD}$ 와의 관계 강화를 위해 탁신총리가 2003.5 월, 외교부장관이 2004. 5월 $\mathrm{OECD}$ 를 방문, $\mathrm{OECD}$ 와의 협력관계 증진 방안을 논의함.

- 태국 외교부(국제경제국)는 $\mathrm{OECD}$ 및 회원국과 의 관계증진을 위해 4 가지 목표를 설정하여 추 진 중임.

(1) $\mathrm{OECD}$ 개발센터의 정식회원 자격 획득 (2004.11월)

(2) OECD 및 부속기구를 위한 회의 및 글로벌포럼 주최

-조화와 일치(alignment)를 위한 지역 워크숍 (2004.10.19 20)

• 무역에 관한 글로벌포럼(2004.11.3-4)

- 아시아 개인연금에 관한 회의(2005.4.27-28)

(3) $\mathrm{OECD}$ 위원회 옵서버 자격 신청

- 농업위원회 옵서버 자격 신청(현재 $\mathrm{OECD}$ 에서 검 토 중)

-2004.12. 무역위원회 옵서버 자격 신청(2005.2. $\mathrm{OECD}$ 에서 심의를 위한 질의서 송부)

- 어업위원회 옵서버 자격 신청 고려중

(4) 방콕에 $\mathrm{OECD}$ 출판물 보존 도서관 개관 예정 (2005.12.) 
〈2003년도 태국 ODA 실적〉

\begin{tabular}{|c|c|c|c|}
\hline 구 분 & 담당부처 & 지원내용 & 지원금액 \\
\hline 무상원조 & $\begin{array}{c}\text { 외교부 } \\
\text { TICA 및 타부처 } \\
\text { 재무부 } \\
\text { 교육부 } \\
\text { 보건부 } \\
\text { 교통부 }\end{array}$ & $\begin{array}{l}\text { UN 기여금 } \\
\text { 양자간 협력사업, 장학생제도 및 연수프로그램 } \\
\text { ADB의 아시아개발기금 기여금 } \\
\text { 장학생제도 및 교사연수 } \\
\text { Global Fund, AIDS 치료약(ARV) 및 콘돔 배포 } \\
\text { 라오스. 미얀마 교량 건설, 캄보디아 도로 건설 }\end{array}$ & $\begin{array}{c}7,800,000 \\
5,765,000 \\
841,700 \\
68,800 \\
1,061,500 \\
4,422,000\end{array}$ \\
\hline 소계 & - & - & $19,959,000$ \\
\hline 유상원조 & $\begin{array}{c}\text { 재무부 } \\
\text { 태국수출입은행 } \\
\text { 태국수출입은행 } \\
\text { 태국수출입은행 }\end{array}$ & $\begin{array}{l}\text { 캄보디아, 라오스, 미얀마의 인프라 구축 } \\
\text { 라오스의 댐 및 발전소 건설 } \\
\text { 몰디브의 인프라 및 주택 지원 } \\
\text { 캄보디아의 호텔 및 주택 지원 }\end{array}$ & $\begin{array}{l}48,820,000 \\
60,000,000 \\
30,000,000 \\
8,400,000\end{array}$ \\
\hline 소계 & - & - & $147,220,000$ \\
\hline 차관상환 & - & - & 0 \\
\hline 순 유상원조 & - & - & $147,220,000$ \\
\hline ODA 총계 & - & - & $167,179,000$ \\
\hline
\end{tabular}

출처: ‘Global Partnership for Development' (태국외무부, UN Country Team in Thailand, 2005년)

〈태국 국제협력 프로그램(TICP)〉

(단위: 백만 바트)

\begin{tabular}{|c|c|c|c|c|c|}
\hline 구분 & 2000년도 & 2001년도 & 2002년도 & 2003년도 & 2004년도 \\
\hline \multicolumn{6}{|l|}{ 1. 외교부 지원 } \\
\hline 캄보디아 & 48.80 & 36.65 & 29.24 & 69.61 & 30.54 \\
\hline 라오스 & 14.58 & 22.15 & 30.49 & 31.21 & 47.87 \\
\hline 미얀마 & 16.70 & 3.95 & 2.71 & 2.91 & 5.54 \\
\hline 베트남 & 9.10 & 21.49 & 13.27 & 15.85 & 17.57 \\
\hline 동남아시아1) & 1.58 & 2.94 & 6.81 & 19.77 & 22.46 \\
\hline 동아시알) & 4.34 & 7.69 & 10.016 & 5.72 & 8.62 \\
\hline 남아시앛) & 0.97 & 10.60 & 15.54 & 29.83 & 19.94 \\
\hline 태평양국가4) & 0.97 & 0.05 & 0.016 & 0.069 & 0.069 \\
\hline 아프리카5) & 0.24 & 0.41 & 2.143 & 4.191 & 2.137 \\
\hline 기타 & 15.90 & 7.07 & 7.299 & 13.11 & 16.26 \\
\hline 소계 & 113.18 & 113.04 & 117.54 & 192.10 & 170.47 \\
\hline 2. 타부처 지원 & - & - & - & 35.94 & 160.00 \\
\hline 총계 & 113.18 & 113.04 & 117.54 & 228.04 & 330.47 \\
\hline
\end{tabular}

출처: TICA, Ministry of Foreign Affairs

1) 인도네시아, 말레이시아, 필리핀, 동티모르

2) 중국, 북한, 몽골

3) 아프간, 방글라데시, 부탄, 인도, 몰디브, 네팔, 파키스탄, 스리랑카

4) 피지, 미크로네시아, PNG, 사모아, 솔로몬군도, 바누아투

5) 지부티, 이디오피아, 케냐, 레소토, 마다가스카르, 말라위, 모리셔스, 모로코, 모잠비크, 세네갈, 세이셸, 소말리아, 탄자니아, 우간다, 짐바브웨 


\section{III. 관찰 및 의견}

\section{1. 태국과의 공동협력사업 추진}

대태국은 인접 최빈국에 중점적으로 원조를 공여하 면서 역내 단일경제권 통합을 주도하는 등 아세안 회원국들의 중심국가로 부상하고 있음. 이에 따라 일본 등 일부 선진국들은 동남아 진출을 위한 교 두보 확보 차원에서 태국과 공동협력사업을 펼치 고 있는 바, 우리도 대 아세안 협력의 영역을 넓히 고 기반을 확보하는 차원에서 태국과의 공동협력 사업을 발굴, 추진할 필요성이 있다고 판단됨.

\section{2. 양국 원조기관간 협력체제 구축 필요}

TICA 및 유상원조기관 $\mathrm{NEDA}(2005.4$ 월 설립)와 한국의 원조정책 당국간의 정기적인 정책협의회 개최 등 긴밀한 협력체제 구축을 통해 우리의 원 조정책 수립 및 사업수행 경험 등을 전수함으로써 양국간 우호협력관계를 한층 강화시킬 필요가 있 을 것으로 사료됨.

\section{N. 협력방안}

\section{1. 공동협력사업}

ㅁ 인접 최빈국의 인력을 태국 국경지역의 훈련센터로 초청하여 한 - 태 공동으로 기술훈련 등을 실시함. 〈예시〉

(1) 치앙센 국제직업훈련원에서의 공동연수사업

(2) 팡아지역 TICA훈련소 건립 공동프로젝트사업
(동건은 현재 총리의 재가를 대기중에 있음.)

\section{2. 동남아지역 본부 설치}

ㅁㅌㅌㄱ국은 동남아지역과의 정치 · 외교 및 경제적인 협력관계에 있어 거점국가이며 UNESCAP 및 여 러 국제기구 지역사무소가 위치하여 지역차원의 경제, 사회 등 분야에서 협력의 구심체 역할을 수 행하고 있는 바, 아국의 원조를 총괄하는 동남아 지역 본부를 태국에 설치하고 우리의 원조 당국의 임원급 인사를 총책임자로 파견하는 등에 대한 검 토가 필요함.

\section{AIT와의 협력강화}

ㅁ 방콕 인근에 소재한 아시아공과대학(AIT)은 석 · 박사과정의 국제교육기관으로 아시아 지역 개도 국의 인재양성을 통해 동 지역의 지속가능한 개발 에 크게 기여하고 있음.

동 대학과의 협력강화시 아시아 개도국의 인재를 양성하는 과정에 한국이 직접 참여함으로써 동 지 역국가들의 경제사회 발전에 실질적이며 장기적 인 기여가 가능하고, 미래의 아시아지역 지도자들 에게 한국의 좋은 이미지를 심어주어 향후 양국간 우호협력관계를 강화하는 인맥으로 활용 가능한 바, Korea Endowment Fund 50만불의 추가 제 공, 파견교수 증원(1명 $\rightarrow 3$ 명), 현재 AIT와 KIST, 환경관리공단, 수자원공사 등이 실시하고 있는 산 학협력 확대 등을 협력방안으로 검토할 수 있음.

[자료 : 주태국 KOICA사무소] 